76. Plebejus aquilo lacustris Freeman, (Lycaena aquilo rustica Edw.) - The Arctic Blue.

77. Everes amyntula albrighti Clench, (Lycaena amyntula)-The Western Tailed Blue.

78. Glaucopsyche lygdamus couperi Grote, (Lycacna couperi) - The Silvery Blue. A species flying in late May and June which Fitch only found in the boreal region north of the North Saskatchewan River.

79. Celastrina argiolus lucia (Kby.), (Lycaena lucia) - The Spring Azure.

I am grateful to Patrick J. Conway of Chicago, Illinois for the loan of his correspondence file with R. J. Fitch and for the loan of specimens in his collection that were collected by Fitch; to L. Paul Grey of Lincoln, Maine for help in the analysis of Speyeria species collected by Fitch; and to W. Harvey Beck of the Manitoba Museum of Man and Nature for the loan of the G. Shirley Brooks correspondence file which contains a series of letters with R. J. Fitch.

\section{LITERATURE CITED}

Bowman, K. 1951. An annotated list of the Lepidoptera of Alberta. Canadian J. of Zool., $29: 121-165$.

Brodie, H. J. 1929. A preliminary list of the Lepidoptera of Manitoba. Trans. Royal Canadian Inst., $17: 81-101$

Brooks, G. S. 1942. A checklist of the butterflies of Manitoba. Canadian Ent., 74:31-36.

Ehrlich, P. R. \& A. H. Ehrlich. 1961. How to know the butterflies. Wm. C. Brown Co.. Dubuque, Iowa.

Masters, J. H. and J. T. Sorensen, 1968. Bionomic notes on the satyrid butterfly, Oeneis macounii at Riding Mountain, Manitoba. The Blue Jay, 26(1):38-40.

Puckering, D. L. and R. L. Post, 1960. Butterflies of North Dakota. Publ. 1., Dept. of Agr. Ent., North Dakota Agricultural College.

Wallis, J. B. 1921. A colour key to the Manitoban butterflies. Nat. Hist. Soc. Manitoba Publ.

\title{
AN OBSERVATION OF INTERSPECIFIC BEHAVIOUR IN DRAGONFLIES
}

by Victoria Rider, 824 New Hampshire Ave. N.W., Washington, D.C.

During the summer of 1968 at Emma Lake, Saskatchewan, a male Aeshna interrupta dragonfly was seen to exhibit both sexual and aggressive, or predatory, behaviour toward a male Libellula quadrimaculata dragonfly. The observation was recorded during the course of a preliminary study of aggressive behaviour in L. quadrimaculata in which males of the species were glued live, by the legs, to frequently used perches projecting over shallow water areas. Usually these libellulid "models" were investigated by other male $L$. quadrimaculata. On one occasion, however, a male Aeshna interrupta landed on the thorax of the model and appeared, initially, to be attacking it vigorously with its mandibles. It subsequently remained nearly motionless for the next few minutes, still perched on the model's thorax. The aeshnid then began curving its abdomen forward and succeeded in grasping the model anteriorally for a few seconds with its abdominal claspers. This last act strongly resembled normal mating behaviour in dragonflies, where the male's first action is to adopt the "tandem position" with the female.

After several more minutes of perching on the model's thorax the $A$. interrupta flew off. The entire interaction lasted approximately six minutes. Examination of the L. quadrimaculata model revealed that a large section of the dorsal side of its thorax and the back of its head had been eaten.

This interaction is significant in two respects. First, it demonstrates the relatively low degree of speciesspecificity which can characterize interactions between dragonflies. Aeshna interrupta is a considerably larger species than Libellula quadrimaculata, and the bodies of male aeshnids display brilliant blue and yellow coloring in contrast to the brown coloration of $L$. quadrimaculata. A. interrupta dragonflies spend the vast majority of their active hours on the wing, frequently flying at 


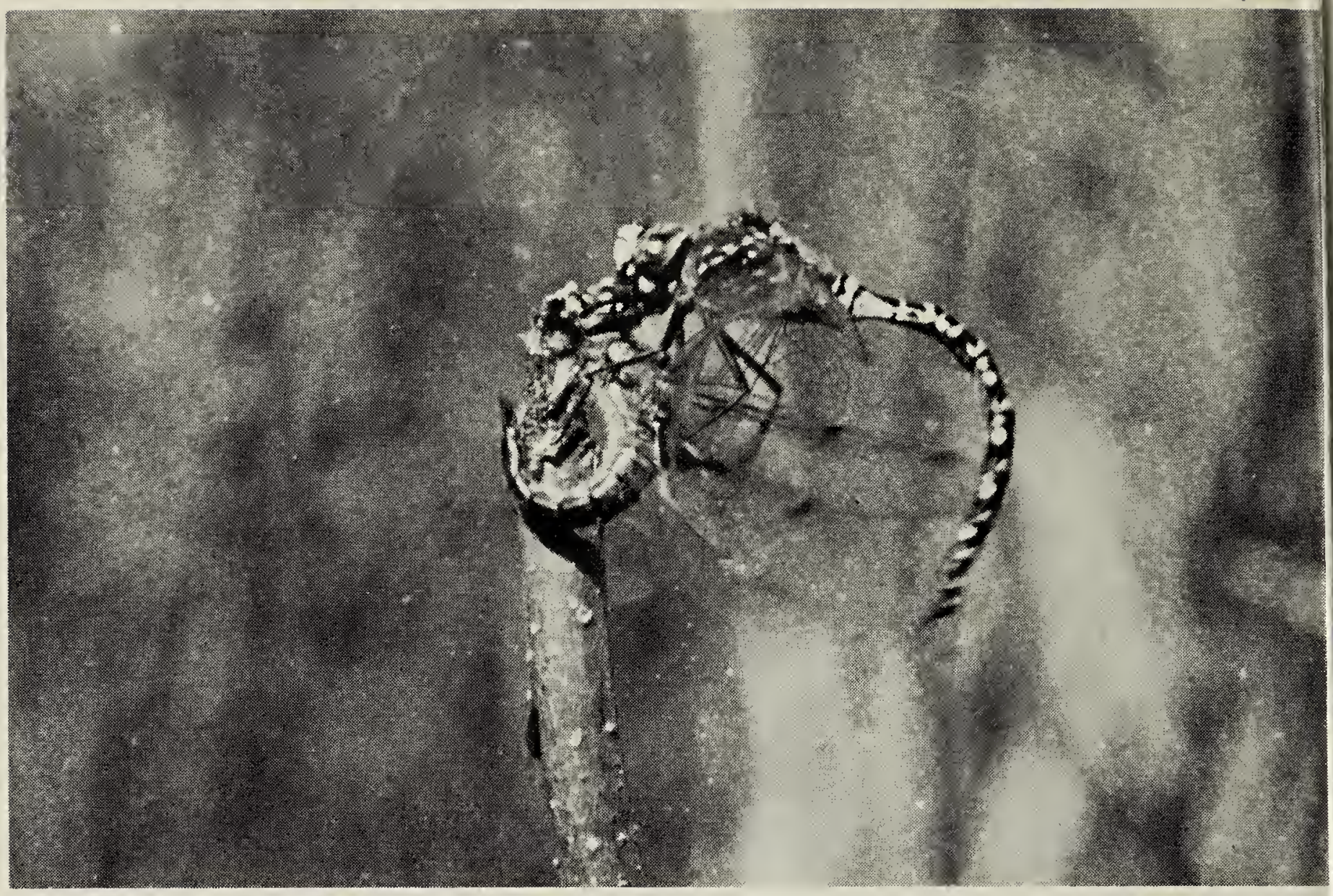

Initial contact of a male Libellula quadrimaculata "model" by male Aeshna interrupta.

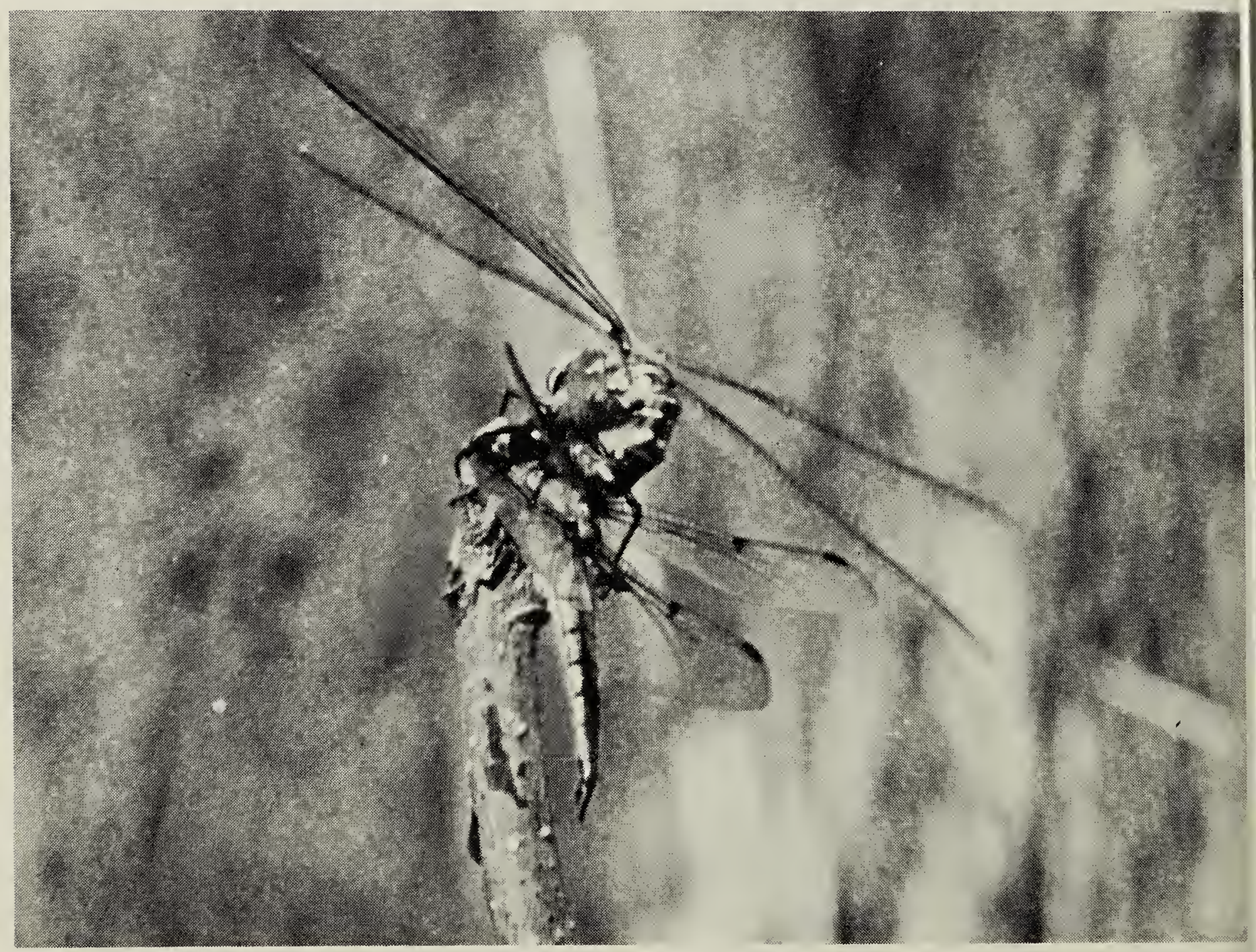

Aeshna interrupta attempting to achieve tandem position with Libellula quadrimaculata. 
heights of four feet or higher. Male L. quadrimaculata are territorial, spend an average of 90.5 per cent of their time perching and rarely fly higher than three feet (Connor, 1968). Despite differences in appearance, flight ranges and behaviour, however, there are apparently enough general similarities between the two species to provoke occasional interactions. Miller (1967) has even observed a male $A$. interrupta attempting to couple with a Ruby-throated Hummingbird (Archilocus colubris).

Studies of dragonflies are frequently complicated by the difficulty of resolving behaviour into sexual and aggressive components. In this interaction both sexual and predatory responses by the Aeshna interrupta seemed fairly evident. Furthermore, the interaction is consistent with the finding of Pajunen (1962) and others that in a single encounter between two male dragonflies both sexual and aggressive behaviour may be displayed.
On the subject of dragonflies eating other dragonflies Moore (1960) has noted that although the initial response of the attacker may be either aggressive or sexual, once the attacker's mouthparts come in contact with the other individual, the latter may be eaten essentially by accident. At Emma Lake Aeshna interrupta were seen to capture and devour Sympetrum danae but these dragonflies, most probably because of their small size, were never contacted sexually.

\section{LITERATURE CITED}

Connor, W. F. 1968. Territorial relationships of the dragonfly Libellula quadrimaculata $L$. Master's thesis, University of Saskatchewan, Saskatoon.

Miller, R. S. 1967. Further observations on interactions between dragonflies and hummingbirds. Blue Jay, $25: 185-186$.

Moore, N. W. 1960. Dragonflies. Collins, London. 260 pp.

Pajunen, V. I. 1962. A description of aggressive behavior between males of Leucorrhinia dubia v.d.Lind. (Odon., Libellulidae). Ann. Entom. Fenn., 28:108-118.

\section{SHORT-TAILED SHREW AT NIPAWIN \\ by L. S. Riome, Nipawin}

April 21, 1968 was a raw windy day. The temperature at noon was $33^{\circ}$ above zero, the ice on the Saskatchewan River was still intact, snow was deep in the forest while the north and east river and ravine banks had begun to succumb to the penetrating spring sun and show patches of expectant black earth. On such a leafstrewn spot an expired Short-tailed Shrew (Blarina brevicauda manitobensis) was found. The location was NW 14-51-14 W2-which subsequently became known as the "Beaver Dam" area to those who participated in the 1968 Summer Meeting of the Saskatchewan Natural History Society at Nipawin.

The animal appeared to be in perfect condition. No signs of external injury were visible. Whether it died of natural causes or had been killed by an enemy was not known. The general shape was that of a stocky mouse with a tapered snout and a short tail. Its incredibly soft, silky fur gave off a variable grey lustre when stroked in strong light. Two very formidable, black-tipped upper incisors protruded under the flexible, sensitive snout giving a buck-toothed appearance. A profusion of long whiskers curved posteriorly. The ears were concealed and the tiny eyes beady. The feet were pinkish with five slender toes terminated by sharp nails. The tail was tipped with a brush of hairs indicating that the animal was young, for as a shrew ages, the hair is worn off leaving the tip eventually hairless.

The specimen, a female, had the following measurements: body $94 \mathrm{~mm}$; tail $24 \mathrm{~mm}$; total length $118 \mathrm{~mm}$; hind foot $14 \mathrm{~mm}$; weight 18 grams. It is now in the collections of the Saskatchewan Museum of Natural History, Regina. 